\title{
EFFECT OF LEAD ACETATE ON HISTOOGICAL FEATURES OF LIVER, SKELETAL MUSCLE AND TESTIS AND SERUM TESTOSTERON LEVEL OF LABORATORY ALBINO MICE Mus musculus.
}

\author{
Sulaf mustafa mohammed*
}

Date of acceptance $\quad 1 / 3 / 2010$

\begin{abstract}
Lead acetate as one of the environmental pollutants can threats the life of living creatures in many ways, it has a long half-life, accumulates mainly in the soft tissue and leads to adverse effects in these tissues. An experiment was conducted to study the effect of oral feeding of lead acetate on histological features of liver, kidney, testis and muscle of albino mice. Mice were treated with $0.05 \mathrm{mg} / 100 \mathrm{ml}$ lead acetate (LA) for 10 days (group A) and for and for 20 days (group B) and for 30 days (group C).

The histological section of liver of mice group A characterized by slightly blurred trabecular structure with foci of hepatitis which increased with cytoplasmic vacules in group B but in group C liver reveal necrosis, heamorrhage, hepatitis with dysplasia. Testis revealed foci of spermatic hypoplasia in group A, areas of fibrosis and spermatic arrest revealed in group B and $\mathrm{C}$ with mild degree of maturation in last group. Skeletal muscle fibers not changed in group A but characterized with focal mononuclear cell infiltration and myositis in group B but necrosis and skeletal muscle atrophy with increase perimuscular adipose tissue and fibrosis revealed in fibers of group C.
\end{abstract}

Key words: Lead; acetate; liver ; kidney, skeletal muscle, testis, histology, testosterone

\section{Introduction}

Due to the industrial processes and smokes from petrol vehicle, lead is considered as one of the major environmental pollutants (1). Although lead is eliminated from petrol in many countries, but it may have other origins such as industrial pollution $(1,2)$. One of the main problems with heavy metals is their ability to bioaccumulate.

Bio-accumulation means the metals do not leave the body by their own accord; instead they accumulate in certain tissues. Due to bioaccumulation, heavy metals are passed up the food chain from smaller species (fish) to humans. The main tissues targeted by heavy metals include the liver, kidneys, The main organs of excretion for heavy metals include: liver, kidneys, and lungs, digestive tract and skin. If these organs are not excreting efficiently during the metal detoxification process, the individual may become more toxic and experiencing more symptoms (3). There are evidences, which show that lead is a toxic agent with multiple target organs (4). Liver and kidney are important organs of metabolism, detoxification, storage and excretion of xenobiotics and their metabolites, and

\footnotetext{
* Department of biology, college of science , university of sulaimani 2009
} 
are especially vulnerable to damage. As the liver is an important target organ, and the kidney of heavy metal toxicity $(4,5) .(6)$ showed that The histoarchitecture of the liver was grossly intact after exposing to heavy metal.The histochemistry

histopathology of hepatic cells of albino rats were affected by heavy metal because level of glycogene and protein decreased in the hepatocytes and histopathological study showed pyknotic, degenerative and binucleated nuclei,vacuolization, and hepatocellular fluid accumulation inside centrilobular region (7).( 8) showed that the ;heavy metal induced neurotoxicity includes skeletal muscle symptoms (extremity weakness and wasting, muscle cramp) in addition to ataxia and disturbances of sensory and visual function. In this study the effects of $\mathrm{MeHg}$ exposure on skeletal muscle were investigated in rats receiving orally administered $\mathrm{MeHgCl}$ at 5 $\mathrm{mg} / \mathrm{kg} /$ day for 12 days.

Accumulated data suggest there is a close relationship between declining reproductive health andenvironmental pollutants like lead (9).Reproductive dysfunction by lead has distinct morphological and biochemical features such as disorganized epithelia, decrease sperm quality, and alter sperm morphology, and low androgen levels (10,and 11)

In the animal model, lead has a primary toxic affect on the hypothalamicpituitary unit, a primary effect on the testes, and acts at all levels of the reproductive axis (12).

(13)They showed that the Single intraperitoneal injection of lead acetate to Swiss mice stimulatedtesticular weight loss with a constant increase in the incidence of abnormal sperm population anddecrease in the total sperm count.
$\mathrm{LH}$ is primarily responsible for stimulating testicular Leydig cell secretion of testosterone. In the animal model, lead has a primary toxic affect testes, and acts at all levels of the reproductive axis.lead exposure produces a dose-response suppression of serum testosterone and spermatogenesis( 14).

\section{Materials and Methods:}

\subsection{Animals:}

Twenty four (weight 250-300g) mature male mice of 6 weeks age were housed in plastic cages measuring about $(29 \times 15 \times 12) \mathrm{cm}$, with about four rats per cage. Floors of cages were covered with soft crushed wood shaving; all cages were washed two times per week with $70 \%$ alcohol throughout the period of the study.

The animals were kept in the animal house of Sulaimani university thus in an air conditioned room with an optimum temperature of $24 \pm 2{ }^{\circ} \mathrm{C}$ and exposed to about 12-14 hours/day light program, these conditions represent the optimum environmental conditions which are required by the mice. During the period of the experiment abnormal and sick mice were excluded. Water and food was locally prepared and consists of available constituents which fulfill the mice dietary requirements.

\subsection{Experimental design:}

Twenty four mature male mice at the age of six weeks were included in this study. The present work was first divided the 24 mice into four groups as the following:

1. Control group: this group was orally administrated normal saline during the four weeks period of the experiment.

2. treated Group: this group was orally administrated of $0.05 \%$ lead acetate during the 10 dayes period of the experiment. 
3- treated Group: this group was orally administrated $0.05 \%$ of lead acetate during the 20 dayes period of the experiment.

4-treated Group: This group was orally administrated $0.05 \%$ lead acetate during the 30 dayes period of the experiment.

At the end of the period of treatment, blood was collected by heart puncture and serum was separated to estimate testosterone level.

Histology: Liver, testes and skeletal muscle were isolated and fixed in $10 \%$ neutral buffered formalin for 72 hours, and dehydrated through increasing concentrations of ethanol and embedded in paraffin. Serial sections were cut, and stained with hematoxylin and eosin. (Fisher Scientific).

\section{STATISTICAL ANALYAIA}

We analyzed mean data by analsis of variance and performed post -hoc significant level was $\mathbf{P}<0.01$. Values was mean \pm SEM.We analyzed data using the commercially available software package SPSS (SPSS.Inc, Chicago,IL).

\section{Results:}

Histopathological studies showed that liver of control mice composed of lobules with central vein and peripheral hepatic trads, hepatocytes are arranged in trabeculea and are separated by sinusoids, they are regular with central nucleus and peripheral nucleolus as showed in figure (1).figure (2)showed the effect of lead acetate after 10 days duration on the liver, the trabecular structure is slightly blurred with foci of hepatitis figure (3)showed the effect of lead acetate after 20 dayes. The trabecular structure is blurred with some cytoplasmic vacules, foci of hepatitis and regenerative changes.

Figure (4)showed the effect of lead acetate on liver after 30 dayes. Blurred structure, foci of necrosis heamorrhage, hepatitis with moderate dysplasia and increased foamy vacules in the cytoplasm of hepatocytes.

Figure (5) normal skeletal muscle bundles in control group and treated group for 10 dayes with laed acetate. figure(6) showed skeletal muscle fibers of mice after 20 dayes of treatment it showed focal mononuclear cells, infiltration and features of myositis.

Skeletal muscle of the treated mice for 30 dys reveal in figure (7)features of acute myositis with foci of necrosis and in some of them skeletal muscle atrophy with increased perimuscular adipose tissues and fibrosis

Figure (8)showed normal testes in control group and the treated group after 10 days characterized by normal testicular tubules with primary and secondary spermatocytes and normal degree of maturation.

Testes of treated mice for 20 days revealed areas of fibrosis and spermatocytic arrest with very low degree of maturation and some of them showed moderate degree of maturation as appear in figure (9)

$$
\text { Figure (10)showed spermatic }
$$
hypoplasia but still normal maturation

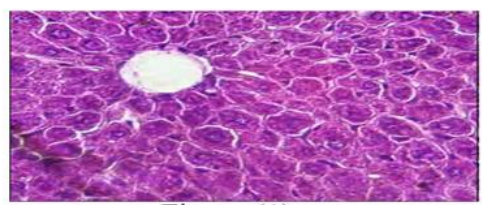

Figure (1)

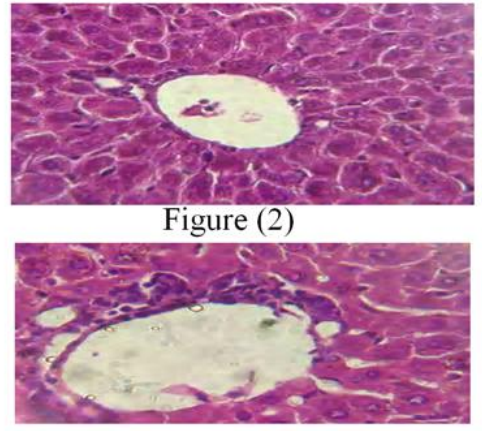

Figure (3) 


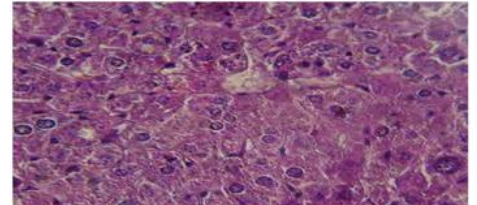

Figure (4)

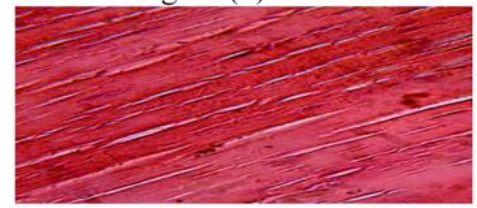

Figure (5)

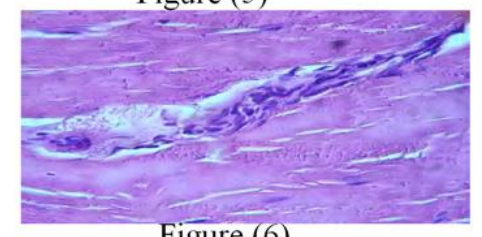

Figure (6)

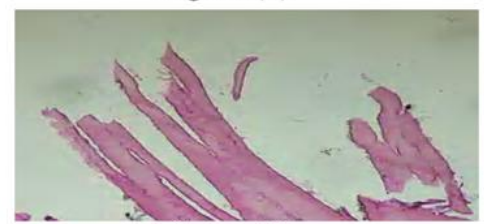

Figure (7)

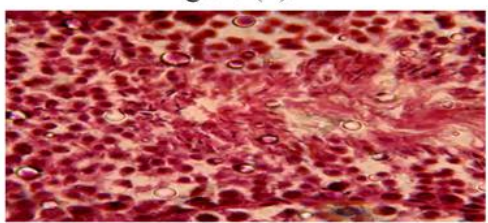

Figure (8)

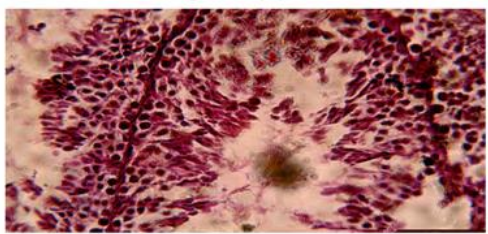

Figure (9)

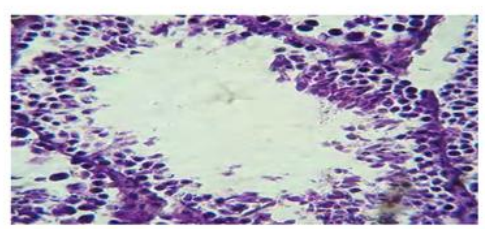

Figure (10)
Table (1) showed that Compared to control mice, lead acetate treated mice had significant decreasing of serum testosteron $(\mathrm{P}<0.01)$, in treated group (T1) fore 10 days duration was $0.35 \pm 0.028$, in

Treated group (T2) for 20 days duration was $0.5 \pm 0.13$ and in treated group (T3) for 30 days duration was $0.37 \pm 0.04$, but in control group was $1.02 \pm 0.062$.

Table 1:Means of serum testosterone in lead acetate treated $(0.05 \%$ for three durations)and control mice.

\begin{tabular}{|c|c|c|}
\hline Testosteron & Means \pm SE & \\
\hline T1(10 days duration) & $0.35 \pm 0.028^{\mathrm{a}}$ & \\
\hline T3(30 days duration) & $0.37 \pm 0.04^{\mathrm{a}}$ & \\
\hline T2(20 days) & $0.50 \pm 0.13^{\mathrm{a}}$ & \\
\hline Zero time & & $1.02 \pm 0.062^{\mathrm{b}}$ \\
\hline
\end{tabular}

\section{DISCUSSION:}

Histopathological studies of liver showed changes which reflect damages in hepatic tissues possibly due to cycling of heavy metal this gains support from (15), and who also observed the same histological changes in liver in rat after exposure to heavy metals. it has been reported that heavy metals forms mercaptides with the$\mathrm{SH}$ (thiol)groups of cysteine and less stable complexes with other amino acide chain (16)and these changes reflect damages in hepatic tissues (17) . skeletal muscle showed features of myositis with foci of necrosis and in some of them skeletal muscle atrophy with increased perimuscular adipose tissues and fibrosis. The histological sections of skeletal muscle of rat treated by lead acetate revealed oedema and necrosis (18) and The histological section revealed oedema and necrosis of dogs muscle after treatment with lead Acetate (19).

Are view of literature suggests that some metal, such as lead, cadmium, arsenic, and mercury can affect male reproductive functions including spermatogenesis (20). 
In the present study, our results clearly demonstrated that exposure of an adult male mice to lead acetate can seriously alter the testes and reproductive tract. Male mice exposed to lead acetate showed an alteration of the normal histological structure.

In the present study, male mice treated with lead acetate exhibited disordered arrangement of germ cells, a decrease spermatogenic cell layer in the seminiferous tubules. These findings support the results from other reports with indicated that lead $(21,22)$ altered testis histology resulting structural defects in spermatids and sperm mice, rat, and rabbits. our result suggest that there is significantly decrease in the level of serum testosterone in the three treated group of mice, One possible explanation is that these compounds may be toxic to testicular histological structure in agreement with other reports (23). Other authors suggest that a principal mechanism of action of lead toxicity at the level of the hypothalamic-pituitary axis or a combined defect involving the gonad and hypothalamic-pituitary sites (24)However, the impairment of spermatogenesis appeared to be as a consequence of the decline of testosterone serum in treated rats since the androgen is clearly essential to the gametogenesis (25). Leydig cells secrete the male hormone, testosterone, which is a prerequisite for the production of sperm. Various studies suggest an interaction of heavy metal with the hypothalamo-hypophysis axis controlling spermatogenesis (26) These products may also interact directly with Sertoli or Leydig cells, responsible for testicular production of proteins involved in the transport and the production of testosterone, respectively. Therefore, lead exposure resulted in oxidative stress and this was well extrapolated from the increase in lipid peroxidation products
(LPP). An increase in LPP damages various cellular components of tissues(26).

\section{References:}

1. Ghorbe, F., Boujelbene, M., MakniAyadi, F., Guermazi, F., Kammoum, A., Murat, Jc., et al. (2001) Effect of chronic lead exposure on kidney function in male and female rats: determination of a lead exposure biomarker. Arch. Physiol. Biochem. 109: 457-463.

2. Patel, A.B., Williams, S.V., Frumkin, H., Kondawar, V.K., Glick, H., Ganju, A.K. (2001) Blood lead in children and its determinants in Nagpur, India. Int. J. Occup. Environ. Health. 7: 11926.

3-Bowring J.,(2005)Heavy metal toxicity and unborn child,midwifery tody,48-49.

4-WHO cadmium.Environmental Health criteria 134 Geneva:World Health organization, 1992.

5-Nordberg, G. F., Jin, T. and Nordberg, M. (1994) Subcellular targets of cadmium nephrotoxicity: cadmium binding to renal membrane proteins in animals with or without protective metallothionein synthesis. Environmental Health Perspectives 102 (Suppl. 3), 191-194.

6- NEHRU B. AND KAUSHAL S.(1993) Alterations in the Hepatic Enzymes Following Experimental Lead Poisoning Vol. 38, 0163-4984.

7- Kanhiya M.and Prabhu U.Saxena (2007)assessment of mercuric chloride intoxication in albino rats on the basis of hepatobiochimstry, serum biochemistry, histochemistry and histopathology, volum 1 ,no.3

8-USUKI F.; YASUTAKE A.; MATSUMOTO M.; UMEHARA F. ;HIGUCHI I.;1998. Toxicology letters, vol. 94, n'3, pp. 227-232. 
9- Bonde JP, Joffe M, Apostoli P, Dale $A$, Kiss $P$, Spano $M$ et al. 2002. Sperm count and chromatin structure in men exposed to inorganic lead: lowest adverse effect levels. Occup Environ Med ; 59 (4), 234-42.

10- Hsu PC, Liu MY, Hsu CC, Chen LY, Leon Guo Y.1997. Lead exposure causes generation of reactive oxygen species and functional impairment in rat sperm. Toxicology; 122 (12): 133-43.

11- Alexander BH, Checkoway $\mathrm{H}$, Van Netten C, Muller CH, Ewers TG, Kaufman JD. 1996. Semen quality of men employed at a lead smelter. Occup Environ Med; 53 (6): 411-6

12- Sokol Rebecca Z, Saixi Wang, YuJui Y, frank Z Stanczyk, Elizabet Gentzschein, and Robert E Chapin. 2002.Long-term, low-dose lead exposure alters the gonadotropinreleasing hormone system in the male rat. Invironmental health Perspectives; 110: 871-874.

13-ACHARYA U.R., S. ACHARYA and M. MISHRA,2003.lead acetate induced cytotoxicity in male germinal cells of swiss mice.industrial health.41,291-294.

14- Ronis MJ, Badger TM, Shema SJ, Roberson PK, Shaikh F. (1996).Reproductive toxicity and growth effects in rats exposed to lead at different periods during development. Toxicol Appl Pharmacol 136:361-371

15-Kanhiya M.and ProbhuN.S. ,2007.Assessment of mercuric chloride intoxication albino rats on the basis of hepatochemistry, serum biochemistry, histochemistry

\&histopathology.Iranian Journal of toxicology. Volume 1, No.3.

16-Vallee,B.L. and Ulmer, D.D.,1972.Biochemical effect of mercury, cadmium and lead .Ann.Rev.Biochem,41:91.
17-Gajawat,s.,sancheli, G and goyal ,P.K.,2005. vitamin C against concomitant exposure to heavy metals and radiation: A study on variations in hepatic cellular counts. Asian J.Exp.sc.

18- Robinson, J.J.Abraham, M. chandran and A.M. shanmugam.(1992)Effect of feedig lead acetate in Albino rats. Chennai600-007

19- Hamir, A.N. and Sullivan,N.D., 1983 acid fast inclusions in osteoclasts of a lead poisoned dog. Veterinary Record, 112:503

20- Telisman S, Colak B, Pizent A, Jurasovic J, Cvitkovic P., 2007. Reproductive toxicity of low-level lead exposure in men. Environ res; 105: 256-266

21-Johansson L, Pellicciari CE. Leadinduced changes in the stabilization of the mouse sperm chromatin. Toxicology 1988; 51: 11-24.

22-Haitao Liu, Ruiyan Niu, Jinming Wang, Ying $\mathrm{He}$, Jundong Wang, Shanxi China. 2008. Changes caused by fluoride and lead in energy metabolic enzyme activities in the reproductive system of male offspring rats. Research report Fluoride; 41 (3): 184-191

23-Ait Hamadouche N ,Slimani M., Merad-Boudia B. and Zaoui C.,2009,Reproductive toxicity of lead acetate in adult male rats ,American journal of scientific research ISSN 1450- $223 \mathrm{X}$ Issue 3,pp.38-50.

24-Thoreux-Manlay A, Vélez de la Calle JF, Olivier MF, Soufir JC, Masse R, Pinon-Lataillade G., 1995.Impairment of testicular endocrine function after lead intoxication in the adult rat. Toxicology ; 26: 101-109.

25-Martin J, Ronis J, Thomas M Badger, Sarah J Shema, Paula K Roberson, Fatima Shaikh., 1996. 
Reproductive toxicity and growth effects in rats exposed to lead at different periods during development Toxicology and Applied Pharmacology; 136: 361-171.

26- Sokol RZ, Saixi Wang, Yu-Jui Wan, Frank Z Stanczyk, Elisabet
Gentzschein, Robert E Chapin. 2002.Long-term dose lead exposure alters the gonadotropin-releasing hormone system in the malerat. Environ Health Perspect; 110 (9): 871-874.

\section{تأثير الرصاص على المواصفات النسيجية للكبا والعضلات والخصية وتركيز التيستوستيرون في الفئران البيض والفيض

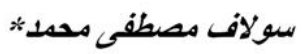

ق قسم علوم الحياة /كلية العلوم / جامعة اسليمانبة

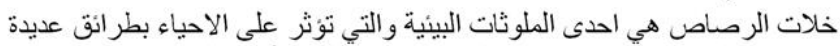

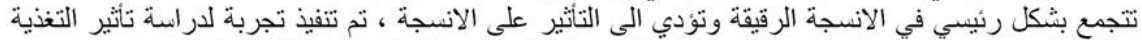

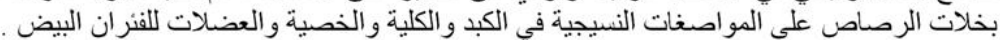

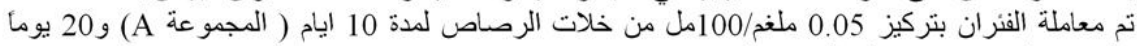

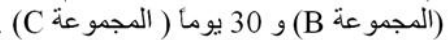

اظهرت المقاطع النسيجية للكبد في المجموعة A

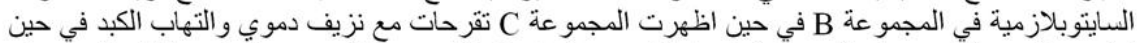

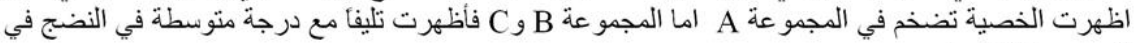

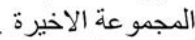
لم تتغير اليفات الجهاز العضلي في المجموعة A واخيرا تليف الالياف في المجموعة C 